\title{
УГОЛОВНО-ПРАВОВАЯ ОХРАНА УСТАНОВЛЕННОГО ЗАКОНОМ ПОРЯДКА ОСУЩЕСТВЛЕНИЯ АРХЕОЛОГИЧЕСКИХ РАСКОПОК: НОВОЕ В ЗАКОНОДАТЕЛЬСТВЕ
}

\begin{abstract}
Аннотация: Предметом исследования являются вопросы уголовно-правовой защиты культурных ценностей, археологического достояния Российской Федерации. Исследование осуществляется на основе анализа изменений действующего российского законодательства об охране объектов культурного наследия, изменений уголовного законодательства об охране данных объектов, внесенных Федеральным законом от 23 июля 2013 года № 245-Ф3; исследуются объективные и субъективные признаки состава преступления, предусмотренного введенной в Уголовный кодекс Российской Федерации статьей 2433; рассматриваются вопросы применения уголовного законодательства и закона об охране культурных иенностей исходя из указанных нововведений. Методологической основой исследования явилась совокупность общенаучных и специальных методов постижения объективной социально-правовой действительности в исследуемой области: методы анализа, синтеза, систематизации и обобщения, формальнологическийметод. В статье исследуются и анализируются важнейшие актуальные аспекты применения диспозиций норм уголовного закона об ответственности об охране культурных ценностей и археологического наследия. Выводы статьи могут быть полезны правоприменительным органам при расследовании и рассмотрении уголовных дел соответствующей категории, студентам, аспирантам, а также всем интересующимся вопросами юриспрудениии. Ключевые слова: Уголовно-правовая защита, археологическое наследие, культурные ценности, законодательство о культуре, уголовное законодательство, диспозиция уголовно-правовой нормы, признаки состава преступления, уголовная ответственность, обстоятельства, исключающие ответственность, археологические полевые работы. Abstract: The subject of this research is the questions of criminal legal protection of cultural and archeological heritage of the Russian Federation. The research is conducted based on the analysis of the changes to the current Russian legislation on protection of the objects of cultural heritage and changes to the criminal legislation on protection of these objects made by the Federal Law \#245-FZ from July 23, 2013. It examines the objective and subjective definitions of a crime provided by the article \#2433 introduced into the Criminal Code of the Russian Federation. A review is given to the issues of implementation of criminal legislation and the law on the protection of cultural heritage based on the new changes stated above. The article analyzes the key relevant aspects of implementing the dispositions of the norms of criminal law on the responsibility of protection of cultural and archeological heritage. The conclusion made in this article can be useful for the law enforcement agencies in investigation and review of criminal cases pertaining to this category, students, post-graduate students, as well as all who are interested in the issues of jurisprudence.

Keywords: Criminal legal protection, Archeological heritage, Cultural heritage, Legislation on culture, Criminal law, Disposition of criminal legal norm, Signs of criminal activity, Criminal liability, Circumstances that exampt from liability, Archeological field work.
\end{abstract}

25 июля 2015 года вступает в силу положение ст. 3 Федерального закона от 23 июля 2013 года № 245-Ф3 «О внесении изменений в отдельные законодательные акты Российской Федерации в части пресечения незаконной деятельности в области археологии», в соответствии с которым в Уголовный кодекс Российской Федерации (далее - УК РФ) вводится новая статья - статья $243^{3}$, устанавливающая уголовную ответственность за уклонение исполнителя археологических работ, осуществляемых на основании разрешения (открытого листа), от обязательной передачи государству в соответствии с законодательством Российской
Федерации обнаруженных при проведении таких работ предметов, имеющих особую культурную ценность, или культурных ценностей в крупном размере.

В качестве квалифицированного состава данного преступления, содержащего признаки, отягчающие ответственность, законодатель установил совершение названного деяния должностным лицом с использованием своего служебного положения, группой лиц по предварительному сговору либо организованной группой.

Объекта преступного посягательства, предусмотренного ст. $243^{3}$ УК РФ, являются общественные 
отношения, направленные на защиту общественной нравственности, поскольку культурные ценности представляют собой общее достояние и богатство народов мира, свидетельства цивилизации и духовные ценности, которые передаются из поколения в поколение.

Предметом посягательства являются предметы, имеющие особую культурную ценность, а также обнаруженные в ходе археологических раскопок культурные ценности в крупном размере.

Диспозиция ст. $243^{3}$ УК РФ по конструкции объективной стороны состава преступления является бланкетной, то есть при применении данной статьи в каждом конкретном случае рассмотрения уголовного дела соответствующей категории правоприменителю необходимо руководствоваться нормами действующего законодательства об объектах культурного наследия, содержащего основные понятия и признаки предмета уголовно-правовой охраны - культурных ценностей и археологической деятельности.

Так, согласно Федеральному закону от 25 июня 2002 года № 73-Ф3 «Об объектах культурного наследия (памятниках истории и культуры) народов Российской Федерации», к числу объектов археологического наследия относятся частично или полностью скрытые в земле или под водой следы существования человека в прошлых эпохах (включая все связанные с такими следами археологические предметы и культурные слои), основным или одним из основных источников информации о которых являются археологические раскопки или находки. Под археологическими предметами понимаются движимые вещи, основным или одним из основных источников информации о которых независимо от обстоятельств их обнаружения являются археологические раскопки или находки, в том числе предметы, обнаруженные в результате таких раскопок или находок [1].

Работы по выявлению и изучению объектов археологического наследия, включая работы, имеющие целью поиск и изъятие археологических предметов, образующие в совокупности археологические полевые работы, проводятся на основании выдаваемого сроком не более чем на один год разрешения (открытого листа).

Поиск археологических предметов и их изъятие из мест залегания могут производиться исключительно в составе археологических полевых работ.

Разрешение (открытый лист) - документ, выдаваемый федеральным органом охраны объектов культурного наследия на основании заключения Российской академии наук и подтверждающий право на проведение одного из видов археологических полевых работ.
Порядок выдачи разрешений (открытых листов), приостановления и прекращения их действия устанавливается Правительством Российской Федерации.

Разрешения (открытые листы) выдаются физическим лицам - гражданам Российской Федерации, обладающим научными и практическими познаниями, необходимыми для проведения археологических полевых работ и подготовки научного отчета о выполненных археологических полевых работах, и состоящим в трудовых отношениях с юридическими лицами, уставными целями деятельности которых являются проведение археологических полевых работ, связанные с проведением археологических полевых работ научные исследования, выявление и собирание музейных предметов и музейных коллекций, а также подготовка кадров высшей квалификации по соответствующей специальности.

Решение о выдаче разрешения (открытого листа) или об отказе в его выдаче принимается федеральным органом охраны объектов культурного наследия с учетом заключения Российской академии наук о целесообразности проведения археологических полевых работ определенного вида в соответствии с заявленными целями, задачами, объемом и методами исследования. В случае выдачи разрешения (открытого листа) лицу, осуществлявшему археологические полевые работы на основании ранее выданного разрешения (открытого листа), новое разрешение выдается при условии принятия на хранение в Архивный фонд Российской академии наук научного отчета о выполненных археологических полевых работах [5].

Физическое лицо, получившее разрешение (открытый лист), обязано не позднее чем за пять рабочих дней до начала проведения археологических полевых работ представить в орган исполнительной власти субъекта Российской Федерации, уполномоченный в области охраны объектов культурного наследия, орган местного самоуправления муниципального образования, на территориях которых планируется проведение археологических полевых работ, уведомление в письменной форме о проведении археологических полевых работ с указанием срока и места их проведения, а также копию разрешения (открытого листа) [3].

К видам археологических полевых работ действующее законодательство об охране культурного наследия относит:

1) археологические разведки, представляющие собой проведение на поверхности земли или под водой научных исследований объектов археологического наследия без осуществления земляных работ либо с 
DOI: 10.7256/1811-9018.2015.2.13830

При цитировании этой статьи сноска на doi обязательна

\section{Право и политика 2 (182) 2015}

осуществлением локальных земляных работ с общей площадью раскопов не более 20 квадратных метров на каждом объекте археологического наследия с исследованием культурного слоя путем заложения шурфов или без такового, в том числе с полным или частичным изъятием археологических предметов из раскопов, в целях выявления объектов археологического наследия, уточнения сведений о них или планирования мероприятий по обеспечению их сохранности;

2) археологические раскопки, то есть проведение на поверхности земли, в земле или под водой научных исследований объектов археологического наследия посредством земляных и связанных с ними работ, в том числе с полным или частичным изъятием археологических предметов из раскопов, в целях изучения и сохранения объектов археологического наследия;

3) археологические наблюдения - проведение научных исследований объектов археологического наследия на поврежденных участках территорий объектов археологического наследия в целях выявления на них археологических предметов и сохранившихся участков культурного слоя и исследуемых методами археологических раскопок конструктивных составляющих объектов археологического наследия.

Лабораторная обработка и научный анализ собранного материала (камеральная обработка) являются неотъемлемой частью археологических полевых работ.

В целях сохранения объектов археологического наследия проводятся предусмотренные законом спасательные археологические полевые работы, осуществляемые посредством применения методов научных исследований объектов археологического наследия с полным или частичным изъятием археологических предметов из раскопов в целях их сохранения и получения научных знаний [2].

Порядок проведения археологических полевых работ, методы научных исследований объектов археологического наследия, состав и структура научного отчета о выполненных археологических полевых работах, требования к профессиональным знаниям и навыкам исследователя определяются Российской академией наук при осуществлении научной регламентации археологических полевых работ.

В случае обнаружения при проведении археологических полевых работ объектов археологического наследия физическое лицо, получившее разрешение (открытый лист), обязано в течение десяти рабочих дней со дня выявления данного объекта письменно проинформировать об этом орган исполнительной власти субъекта Российской Федерации, уполномоченный в области охраны объектов культурного наследия, и направить в указанный орган описание обнаруженного объекта археологического наследия, текстовое и графическое описания местоположения границ указанного объекта, а также перечень географических координат характерных точек этих границ.

В случае, если в результате проведения археологических полевых работ изменились учетные данные объекта археологического наследия (площадь объекта, предмет охраны и другие данные), физическое лицо, получившее разрешение (открытый лист), обязано в течение тридцати рабочих дней со дня завершения археологических полевых работ письменно проинформировать об этих изменениях указанный орган исполнительной власти субъекта Российской Федерации, уполномоченный в сфере охраны объектов культурного наследия.

В случае несоблюдения данного правила, неисполнения предусмотренной законом обязанности исполнителем работ по передаче государству в соответствии с законодательством Российской Федерации обнаруженных при проведении таких работ предметов, имеющих особую культурную ценность, или культурных ценностей в крупном размере, исполнитель подлежит уголовной ответственности по ст. $243^{3}$ УК РФ.

Состав преступления, предусмотренного ст. $243^{3}$ УК РФ, является материальным: в качестве общественно опасного последствия данного деяния уголовным законом предусмотрено наступление ущерба в крупном размере. В соответствии с примечанием к новой статье $243^{3}$ УК РФ крупным размером культурных ценностей признается их стоимость, превышающая сто тысяч рублей.

Субъективная сторона преступления, заключающегося в уклонении от обязательной передачи государству обнаруженных предметов, имеющих особую культурную ценность, или культурных ценностей в крупном размере, характеризуется виновной в форме прямого умысла: лицо осознает особую ценность обнаруженных предметов, предвидит наступление ущерба государству в крупном размере вследствие непередачи данных предметов в надлежащем порядке, и желает наступления соответствующих общественно опасных последствий.

Субъектом преступления предусмотренного ст. $243^{3}$ УК РФ, является специальный субъект - исполнитель археологических полевых работ, то есть физическое лицо, проводившее археологические полевые работы, и а также сотрудник юридического лица, в трудовых отношениях с которым первый состоит. Если в течение трех лет со дня окончания 
срока действия разрешения (открытого листа) обязанность по передаче всех изъятых археологических предметов (включая антропогенные, антропологические, палеозоологические, палеоботанические и иные объекты, имеющие историко-культурную ценность) в государственную часть Музейного фонда Российской Федерации не будет исполнена, в действиях виновного физического лица необходимо констатировать факт наличия признаков уголовно наказуемого деяния, предусмотренного ст. $243^{3}$ УК РФ.

Научный отчет о выполненных археологических полевых работах является основным документом, представляющим результаты проведения археологических полевых работ в соответствии с выданным разрешением (открытым листом) [4].

В научном отчете о выполненных археологических полевых работах в текстовом, графическом, фотографическом и иных видах должны быть представлены полные данные о выявленных и (или) об исследованных объектах археологического наследия и археологических предметах.

Научный отчет о выполненных археологических полевых работах в течение трех лет со дня окончания срока действия разрешения (открытого листа) подлежит передаче исполнителем археологических полевых работ на хранение в Архивный фонд Российской академии наук как составную часть Архивного фонда Российской Федерации.

Использование специальных технических средств поиска и землеройных машин в целях обнаружения объектов археологического наследия и археологических предметов возможно исключительно при осуществлении археологических полевых работ, проводимых на основании разрешения (открытого листа).

При этом под специальными техническими средствами поиска в настоящей статье понимаются металлоискатели, радары, магнитные приборы и другие технические средства, позволяющие определить наличие археологических предметов в месте залегания.

Физические и юридические лица, владеющие археологическими предметами, не вправе отчуждать данные археологические предметы, за исключением случая передачи их государству, случая универсального правопреемства или случаев, рассмотренных выше.

Действующим законодательством предусмотрено также обстоятельство, исключающее уголовную ответственность по ст. $243^{3}$ УК РФ. Например, физические и юридические лица, законно осуществившие ввоз археологических предметов на территорию Российской Федерации, вправе распоряжаться указанными археологическими предметами по своему усмотрению в соответствии с законодательством Российской Федерации.

Физические и юридические лица, владеющие археологическими предметами, вправе помимо передачи их государству и универсального правопреемства отчуждать указанные археологические предметы в порядке, установленном законодательством Российской Федерации о Музейном фонде Российской Федерации и музеях в Российской Федерации, при условии включения указанных археологических предметов не позднее 1 сентября 2016 года в состав негосударственной части Музейного фонда Российской Федерации.

\section{Библиография:}

1. Анисимов И.О. Соотношение понятий «подводное культурное наследие» и «всемирное культурное и природное наследие» // Право и политика. - 2014. - № 7. - С. 996-1004.

2. Зубенко Ю.С. Правовые проблемы охраны археологических находок в Российской Федерации: история и современность // Право и политика. - 2010. - № 1. - С. 36-41.

3. Казакова Ю.А. Эволюция государственного регулирования сферы культуры // Вопросы российского и международного права. - 2011. - № 4. - С. 8-17.

4. Мартыненко И.Э. Проблема повышения эффективности правоохранительной деятельности по предотвращению незаконного присвоения культурных ценностей, полученных в результате нелегальных раскопок // Проблемы укрепления законности и правопорядка: наука, практика, тенденции. - 2010. - № 3. - С. 76-81.

5. Работкевич А.В. Нормативное обеспечение деятельности по охране объектов культурного наследия // Культура: управление, экономика, право. - 2010. - № 3. - С. 2-3.

6. А.В. Сумачев К вопросу о понятии культурных ценностей и совершенствовании административно-правового режима их охраны // Право и политика. - 2012. - 12. - С. $2074-2079$.

7. Дубовик О.Л. Фундаментальное исследование преступления и наказания в истории и культуре России (Рецензия на книгу: Наумов А.В. Преступление и наказание в истории России. В 2 ч. М.: Юрлитинформ, 2014. Ч. I. - 752 с., Ч. II. - 656 с.). // Политика и Общество. - 2014. - 6. - С. 651 - 658. DOI: 10.7256/18128696.2014.6.12381.

8. Акопджанова М.О. О роли уголовно-правовой науки в законотворческом процессе // Политика и Общество. - $2014 .-1$. - C. 76 - 81. DOI: 10.7256/1812-8696.2014.1.9217. 
DOI: $10.7256 / 1811-9018.2015 .2 .13830$

При цитировании этой статьи сноска на dоі обязательна

\section{Право и политика $2(182) \cdot 2015$}

\section{References (transliterated):}

1. Anisimov I.O. Sootnoshenie ponyatii «podvodnoe kul'turnoe nasledie» i «vsemirnoe kul'turnoe i prirodnoe nasledie» // Pravo i politika. - 2014. - № 7. - S. 996-1004.

2. Zubenko Yu.S. Pravovye problemy okhrany arkheologicheskikh nakhodok v Rossiiskoi Federatsii: istoriya i sovremennost'// Pravo i politika. - 2010. - № 1. - S. 36-41.

3. Kazakova Yu.A. Evolyutsiya gosudarstvennogo regulirovaniya sfery kul'tury // Voprosy rossiiskogo i mezhdunarodnogo prava. - 2011. - № 4. - S. 8-17.

4. Martynenko I.E. Problema povysheniya effektivnosti pravookhranitel'noi deyatel'nosti po predotvrashcheniyu nezakonnogo prisvoeniya kul'turnykh tsennostei, poluchennykh v rezul'tate nelegal'nykh raskopok // Problemy ukrepleniya zakonnosti i pravoporyadka: nauka, praktika, tendentsii. - 2010. - № 3. - S. 76-81.

5. Rabotkevich A.V. Normativnoe obespechenie deyatel'nosti po okhrane ob'ektov kul'turnogo naslediya // Kul'tura: upravlenie, ekonomika, pravo. - 2010. - № 3. - S. 2-3.

6. A.V. Sumachev K voprosu o ponyatii kul'turnykh tsennostei i sovershenstvovanii administrativno-pravovogo rezhima ikh okhrany // Pravo i politika. - 2012. - 12. - C. $2074-2079$.

7. Dubovik O.L. Fundamental'noe issledovanie prestupleniya i nakazaniya v istorii i kul'ture Rossii (Retsenziya na knigu: Naumov A.V. Prestuplenie i nakazanie v istorii Rossii. V 2 ch. M.: Yurlitinform, 2014. Ch. I. - 752 s., Ch. II. - 656 s.). // Politika i Obshchestvo. - 2014. - 6. - C. 651 - 658. DOI: 10.7256/1812-8696.2014.6.12381.

8. Akopdzhanova M.O. O roli ugolovno-pravovoi nauki v zakonotvorcheskom protsesse // Politika i Obshchestvo. - 2014. - 1. - C. 76 - 81. DOI: 10.7256/1812-8696.2014.1.9217. 